\title{
JOURNAL.RU
}

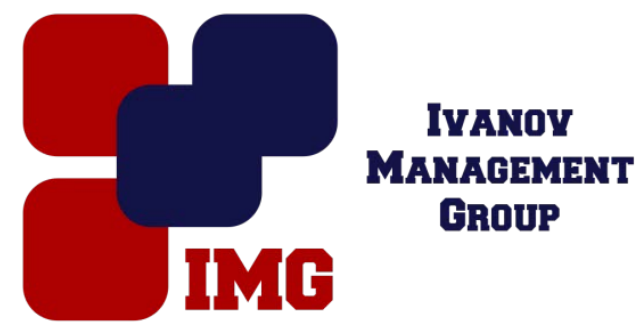

Мощенко А.В., Шмат Е.В. Омский государственный аграрный университет Омск, Россия

doi: 10.18411/lj-30-04-2017-2-09

idsp 000001:1j-30-04-2017-2-09

\section{Ветеринарно-санитарные выводы о вредных и полезных свойствах сливочного масла}

\section{Аннотация}

О сливочном масле известно еще с давних времен. Однако о пользе и вреде данного продукта начали говорить лишь в начале 20 века. Ученые выдвигали предположения о том, что к развитию ишемической болезни могут быть причастны насыщенные жиры и холестерин, которыми богато сливочное масло. Но результаты экспериментов так и не подтвердили эту теорию.

Ключевые слова: сливочное масло, польза, вред, лечебные свойства, кислоты, заболевания.

Польза сливочного масла употребляемого в пищу человеком велика и многогранна. Этот продукт способен регулировать гормональный баланс, улучшать зрение из-за присутствия довольно большого количества витамина $\mathrm{A}$, улучшает состояние кожи, увеличивает работоспособность и уменьшает утомляемость, также положительно влияет на иммунитет из-за присутствия в продукте линолевой кислоты, которая также оказывает блокирующие влияние на развитие метастаз. В составе сливочного масла имеется лауриновая кислота, которая обладает способностью помогать организму в борьбе с грибковыми заболеваниями.

В сливочном масле присутствуют насыщенные жиры, обладающие противоопухолевыми свойствами. Данный продукт также может защищать зубную эмаль от разрушения, так как имеет высокую концентрацию витамина D. Также, в составе масла имеется арахидоновая кислота, улучшающая работу 
мозга.По проведенным исследованиям о пользе и вреде сливочного масла, ученые получили интересный факт, о том, что сливочное масло нормализует репродуктивную функцию и может даже способствовать зачатию. Также врачи рекомендуют принимать масло в качестве средства по устранению желудочнокишечных инфекций, оно нормализует микрофлору ЖКТ.

Бесспорно, сливочное масло обладает и отрицательными свойствами. Данный продукт может нанести удар по фигуре человека из-за высокой калорийности и повысить холестерин, что может вызвать атеросклероз, однако это возможно только при чрезмерном употреблении продукта. Суточная доза сливочного масла составляет 30 грамм, в случае, когда человек болеет и нуждается в повышение иммунитета, употребляемое количество сливочного масла может быть удвоено.

Из выше сказанного можно сделать вывод, что пользы и лечебныхсвойств у сливочного масла намного больше, чем отрицательных, а вред от его калорийности легко можно исправить при помощи правильного и рационального питания. Однако стоит сказать, что наиболее полезно натуральное сливочное масло из коровьего молока, с жирностью от 80 до 85\%. Не стоит заменять сливочное масло спредами, польза их сомнительна из-за содержания опасных жирных кислот трансизомеров, которые вызывают повреждение стенок сосудов и артерий.

1. ГОСТ 32261-2013 Масло сливочное. Технические условия [Электронный ресурс]. - Введ. 2015-07-01. - Режим доступа: http://docs.cntd.ru/document/1200107359, свободный. Заглав. с экрана.

2. Крусь Г.Н., Храмцов А.Г., Волокитина З.В., Карпычев С.В. Технология молока и молочных продуктов: учеб.пособие / Г.Н. Крусь, А.Г. Храмцов, З.В. Волокитина, С.В. Карпычев; Под ред. А.М. Шалыгиной. - М.: КолосС, 2008. - 455 с.

3. Мамаев А.В., Самусенко Л.Д. Молочное дело: учебное пособие / А.В. Мамаев, Л.Д. Самусенко. - СПб. : Издательство Лань, 2013.- 384 с. 